\title{
STRATEGI PENGEMBANGAN USAHATANI JAGUNG UNTUK PENINGKATAN KESEJAHTERAAN MASYARAKAT DI KECAMATAN MAIWA KABUPATEN ENREKANG
}

\author{
oleh \\ Irahmayasari' ${ }^{1}$, Andi Nuddin², Muh Kusnady ${ }^{3}$, Rahmat Mahadir ${ }^{4}$ \\ E-mail: irahmayasari5@gmail.com \\ Program Studi Agribisnis Universitas Muhammadiyah Parepare
}

\begin{abstract}
This study aims to describe the strategies that need to be applied to improve community welfare in Maiwa District, Enrekang Regency. This research was conducted from August to September 2020 in Maiwa District, Enrekang Regency. This study uses Interpretative Structural Modeling (ISM). Research with the ISM method does not require a large sample, so a sample of 15 people was determined. This study uses primary data and secondary data and uses data collection techniques in the form of literature studies, observations and questionnaires. Data processing in this study begins with editing, coding of answers and processing using Interpretative Structural Modeling (ISM). The results of the Interpretative Structural Modeling (ISM) analysis show that the factor of maize farmers switching to other commodities is caused by unstable maize prices and weak commitment of farmers. Furthermore, the strategy that needs to be pursued in improving community welfare.
\end{abstract}

Keywords: Strategy, Farming Development, Corn, ISM

\begin{abstract}
ABSTRAK
Penelitian ini bertujuan untuk mendeskripsikan strategi yang perlu diterapkan untuk peningkatan Kesejahteraan Masyarakat di Kecamatan maiwa Kabupaten Enrekang.Penelitian ini dilaksanakan pada bulan Agustus sampai bulan September 2020 di Kecamatan Maiwa Kabupaten Enrekang.Penelitian ini menggunakan metode Interpretative Struktural Modeling (ISM).Penelitian dengan metode ISM tidak membutuhkan sampel yang besar, sehingga di tetapkan sampel sebanyak 15 orang.Penelitian ini menggunakan data primer dan data sekunder serta menggunakan teknik pengumpulan data berupa studi pustaka, observasi dan kuisioner.Pengolahan data pada penelitian ini di mulai dengan editing, pengkodean jawaban dan processing dengan menggunakan Interpretative Struktural Modeling (ISM). Hasil analisis Interpretative Struktural Modeling (ISM) Menunjukkan bahwa Faktor petani jagung beralih ke komoditi lain di sebabkan oleh harga jagung yang tidak stabil dan lemahnya komitmen petani, selanjutnya strategi yang perlu di upayakan dalam peningkatan kesejahteraan masyarakat.
\end{abstract}

\section{Kata Kunci: Strategi, Pengembangan Usahatani, Jagung, ISM}

\section{A. PENDAHULUAN}

Indonesia merupakan negara agraris, dimana mayoritas penduduk Indonesia berprofesi sebagai petani. Pada tahun 2011, sebanyak 42,48\% penduduk
Indonesia sebagai petani (BPS, 2011). Pemenuhan kebutuhan pangan merupakan target utama pemerintah di bidang pertanian. Selain itu, sektor pertanian juga merupakan penyedia bahan baku penting 
bagi industri, khususnya industri pengolahan makanan dan minuman atau agroindustri dan juga merupakan pilar utama dalam menopang ketahanan pangan negara karena sumbangannya terhadap pemenuhan kebutuhan konsumsi atau kebutuhan pangan sebagian besar masyarakat Indonesia. Pertanian di Indonesia merupakan salah satu sektor yang sangat berperan sebagai mata pencarian masyarakat karena mayoritas penduduk Indonesia bekerja sebagai petani, namun produktivitas pertanian masih jauh dari harapan.

Berdasarkan data Dinas Pertanian Kabupaten Enrekang Sulawesi Selatan, menunjukkan bahwa produksi tanaman jagung pakan dalam lima tahun terakhir mengalami fluktuasi, penurunan yang cukup signifikan terjadi dalam tiga tahun terakhir sehingga rata-rata produksi yang diperoleh hanya sebesar 133.159,6 ton dengan rata-rata luas panen sebesar $33.457,3$ ha dan rata-rata prduktivitas 3,97 ton/ha. Terjadinya fluktuasi produksi ini disebabkan oleh adanya perubahan peningkatan dan penurunan luas panen tiap tahun, adanya faktor cuaca dan iklim yang tidak menentu, gangguan hama dan penyakit yang menyerang tanaman jagung dan terjadinya fluktuasi harga pada input dan sarana produksi, sehingga berdampak pada peningkatan ataupun penurunan jumlah produksi.

Luas panen, produksi dan produktivitas dari tiap-tiap Kecamatan yang berbeda. Kecamatan Enrekang yang mencapai 41.702 ton disusul Kecamatan Maiwa17.702 ton. DiKecamatan Maiwa memiliki potensi pa da komoditas jagungnya, sehingga penge mbangan usahatani tanaman jagung pakan perlu terus ditingkatkan, antara lain dengan pemanfaatan sumber daya yang dimiliki agar usahatani menjadi lebih efisien.

Produksi tanaman jagung pakan di Kecamatan Maiwa sebesar 17.702 ton. Salah satu Desa penghasil jagung pakan yang berada di Kecamatan Maiwa adalah Desa Botto Mallangga dengan luas lahan sebesar 75 ha dan produksi sebesar 285 ton pada tingkat produksi juga sebesar 3,80 ha/ton. Besarnya produksi jagung pakan di Desa Botto Mallangga belum dapat menjamin tingginya pendapatan petani, hal ini disebabkan oleh harga yang diterima petani jagung pakan lebih rendah dari harga yang dibayarkan oleh konsumen.Petani sering kali dihadapkan pada permasalahan seperti permasalahan pemasaran yang setiap tahunnya mengalami penurunan diakibatkan karena pengaruh komoditi lainnya karena pada 
saat musim panennya bertepatan dengan musim panen komoditi lainnya.

Jagung pakan di Kabupaten Enrekang dalam skala relatif kecil dan dengan penggunaan teknologi yang masih sederhana.Keadaan pelaku usaha pertanian tersebut setiap tahun semakin bertambah jumlahnya dengan tingkat kesejahteraan yang masih rendah.Skalausaha pertanian yang masih kecil juga menghambat petani dalam meningkatkan pendapatannya sehingga sulit keluar dari lingkaran kemiskinan.

Untuk mengatasi permasalahan dalam usahatani jagung tersebut, kebijakan yang ditempuh yaitu peningkatan produksi dan kualitas tanaman jagung melalui pengembangan komoditi jagung pemanfaatan dan peningkatan SDM yang di miliki, pengembangan dalam lingkup pemasaran. Menurut Sudrajat, dkk (2014) bahwa efiseinsi pemasaran dapat dilihat dari marjin pemasaran, besarnya share harga yang diterima oleh masing-masing lembaga pemasaran dan share ratsio keuntungan dengan biaya pemasaran. Selanjutnya Desiana, dkk (2017) menjelaskan bahwa fungsi pemasaran itu antara lain fungsi pertukaran, fungsi pengadaan secara fisik dan fungsi pelancar.
Jagung pakan merupakan salah satu komoditas pagan yang cukup menguntungkan untuk dibudidayakan di Kecamatan Maiwa khsusnya di Desa Botto Mallangga karena sekitar 85\% masyarakat usahatani membudidayakan tanaman jagung pakan. Namun saat ini mengalami penurunan berkisar $50 \%$ akibat beralih ke komoditi lain dan untuk mengoptimalkan kembali maka dilakukan penanganan yang optimal sehingga peningkatan

kesejahteraan petani meningkat.

\section{B. METODE PENELITIAAN}

Kabupaten Enrekang adalah salah satu daerah tingkat ke II di Provinsi Sulawesi Selatan.Ibukota Kabupaten ini terletak di Kota Enrekang.Kabupaten ini memiliki luas wilayah $1.786,01 \mathrm{~km} 2$ dan penduduk sebanyak 190.579 jiwa. Secara administratif, Kecamatan Maiwa Kabupaten Enrekang berbatasan langsung dengan :

Sebelah Utara : Kecamatan Enrekang dan Kecematan Cendana

Sebelah Selatan : Kabupaten Sidrap

Sebelah Timur : Kecamatan Bungin

Sebelah Barat : Kabupaten Pinrang

Sebagai gambaran mengenai lokasi penelitian dapat di lihat pada peta administratif Kabupaten Enrekang pada gambar 1. 


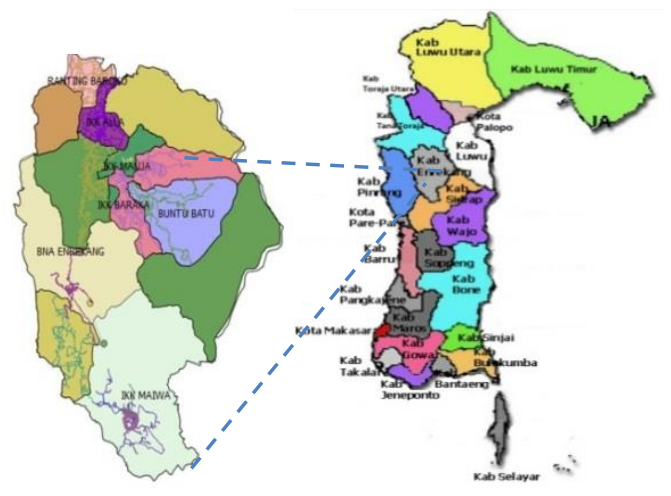

Gambar 1. Peta Lokasi Penelitiaan

Metode penelitian yang digunakan adalah metode kualitatif. Sampel yang digunakan sebanyak 15 orang responden terdiri dari 5 orang terdistribusi dari beberapa instansi dan 10 orang yang terlibat langsung dalam peningkatan usahatani jagung dan pengumpulan data dalam penelitiaan ini di lakukan dengan cara observasi dan wawancara.

Adapun beberapa tahap yang di lakukan dalam teknik ISM yaitu 1). Tahap ini dilakukan pemeriksaan kelengkapan, kejelasan, konsisten dan kesesuian jawaban responden apakah ada kesalahan dalam pencatatan karena kurang dimengerti apa yang di sampaikan,2). Penelitian ini menggunakan kode responden yang sudah tersedia secara baku sehingga penyesuaian daftar kode tidak dilakukan. Kuisioner dalam penelitian ini telah menggunakan kode jawaban V, A, X dan O yang bermakna $: \mathrm{V}=$ adalah eij adalah 1 dan eji adalah 0 , $\mathrm{A}=$ adalah eij adalah 0 dan eji adalah 1 ,
$\mathrm{X}=$ adalah eij adalah 1 dan eji adalah 1,O $=$ adalah eij adalah 0 dan eji adalah $0,1=$ ada hubungan kontekstual antara elemen, 0 =tidak ada hubungan kontekstual antar elemen, 3). Setelah data terkumpul dan diperiksakan kelengkapannya, selanjutnya data dikelompokkan sesuai dengan rencana analisis yang akan dilakukan, oleh data dengan menggunakan analisis ISM. Interpretative Structural Modeling (ISM), digunakan untuk menganalisis data/informasi tentang strategi pengembangan usahatani jagung. Tahaptahap dalam analisis ISM menurut Eriyatno \& F.Sofyar.2007 sebagai berikut

1. Menyusun Structural Self-Interaction Matrix (SSIM) yaitu masukkan (penilaian) dari responden terhadap sub-sub elemen sebelumnya, sebagai hasil pertimbangan hubungan konstektual, dengan menggunakan symbol V, A, X dan O.

2. Menyusun Reachability Matrix, dengan mengganti symbol V, A, X, O dengan angka 1 dan 0.

3. Menyusun model structural (tingkat elemen) setiap elemen.

4. Menyusun Matrik Driver PowerDependent (DP-P) yang terdiri dari empat sektor : 


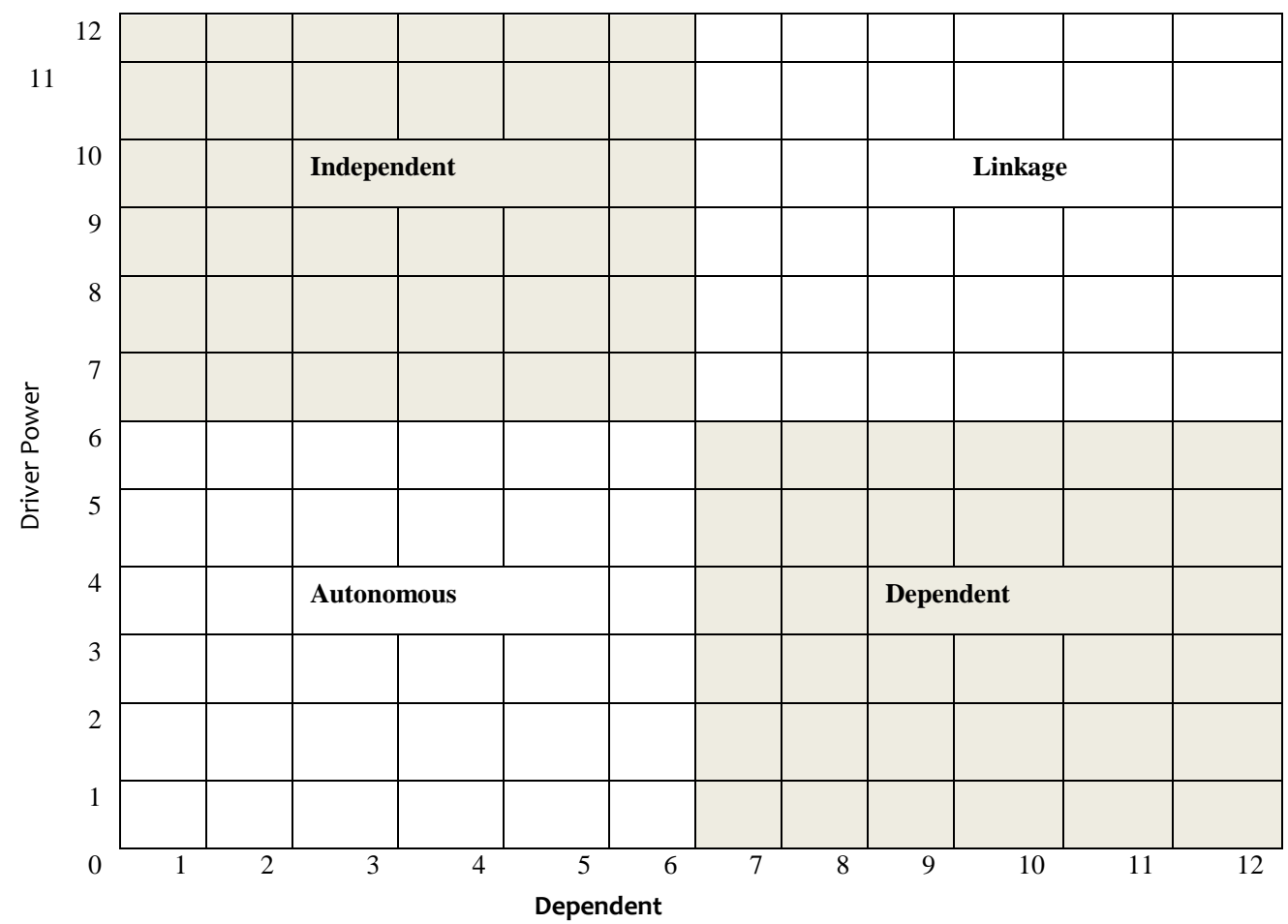

Gambar2. Matrik Driver Power Dependent(DP-D)

Sektor I : Autonomous, sub-elemen di sektor ini tidak berkaitan dengan system, atau hubungannya sangat kecil.

Sektor II : Dependent, Sub-element ini berarti tidak bebas, dimana semua sub-element yang ada di dalamnya merupakan akibat dari tindakan terhadap sub-elemen lainnya. Maka dari itu sub-elemen yang ada di posisi ini tidak penting dalam hubungan program.

Sektor III:Lingkage, sub-elemen yang ada di sektor ini sangat penting dan harus dikaji secara hati-hati, karena hubungannya dengan sub-elemen lainnya tidak stabil. Maka dari itu setiap tindakan pada sub-element tersebut akan menghasilkan sukses, sebaiknya lemahnya perhatianterhadap sub-elemen ini akan menyebabkan kegagalan program.

Sektor IV: Independent, sub-elemen di sektor ini merupakan variable bebas dimana kekuatan penggerak yang besar (driverpower), tetap hanya punya sedikit ketergantungan terhadap yang lain. 
C. HASIL DAN PEMBAHASAN

1. Faktor-faktor yang menyebabkan sehingga banyak petani jagung yang beralih ke komoditi lain.

Hasil analisis Interpretative Struktural Modelling (ISM) menunjukkan bahwa dari 12 sub elemen (faktor) yang diduga, 7 sub-elemen diantaranya merupakan faktor yang paling menyebabkan petani jagung beralih ke komoditi lain. Diantara 1 bagian ada 1 diantaranya sebagai faktor kunci, yaitu (1) harga jagung yang tidak stabil. Faktor tersebut memiliki daya penggerak yang besar terhadap peningkatan kesejahteraan petani jagung.Perbandingan nilai driver power dan dependen masing-masing faktor penyebab banyak petani jagung beralih ke komoditi lain dapat dilihat lebih jelas pada gambar 3 .

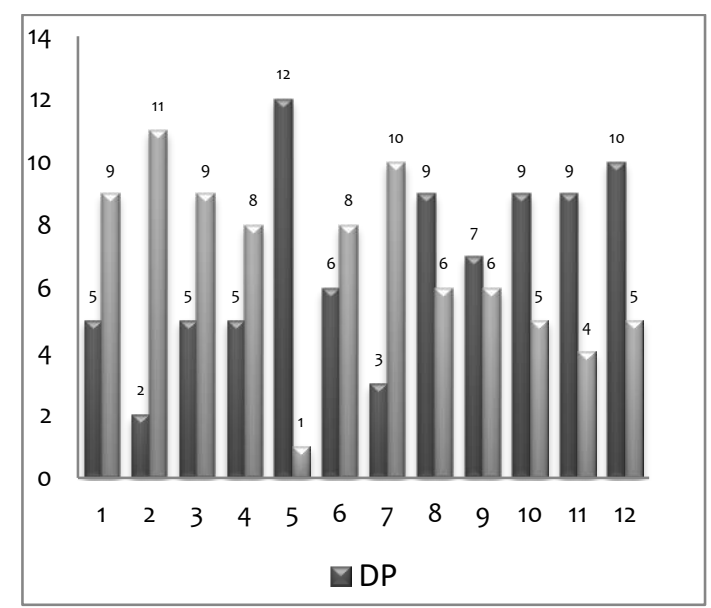

Gambar 3. Diagram Perbandingan Nilai

Driver Power (DP) dan Dependent (D) factor faktor penyebab banyak petani jagung beralih kekomoditi lain.

Keterangan:

1. Mahal dan kurangnya benih unggul

2. Proses penanganan pasca panen yang kurang maksimal

3. Rendahnya tinggat pengetahuan petani

4. Kurangnya perhatian pemerintah daerah

5. Harga jagung yang tidak stabil

6. Lemahnya peran penyuluh

7. Tidak tersediahnya akses trasportasi

8. Kurangnya pupuk bersubsidi

9. Kurannya modal petani

10. Gangguan hama

11. Lemahnya Gapoktan

12. Lemahnya komitmen petani

Posisi faktor-faktor penyebab petani jagung beralih ke komuditi lain dapat dilihat jelas pada Gambar 4. 


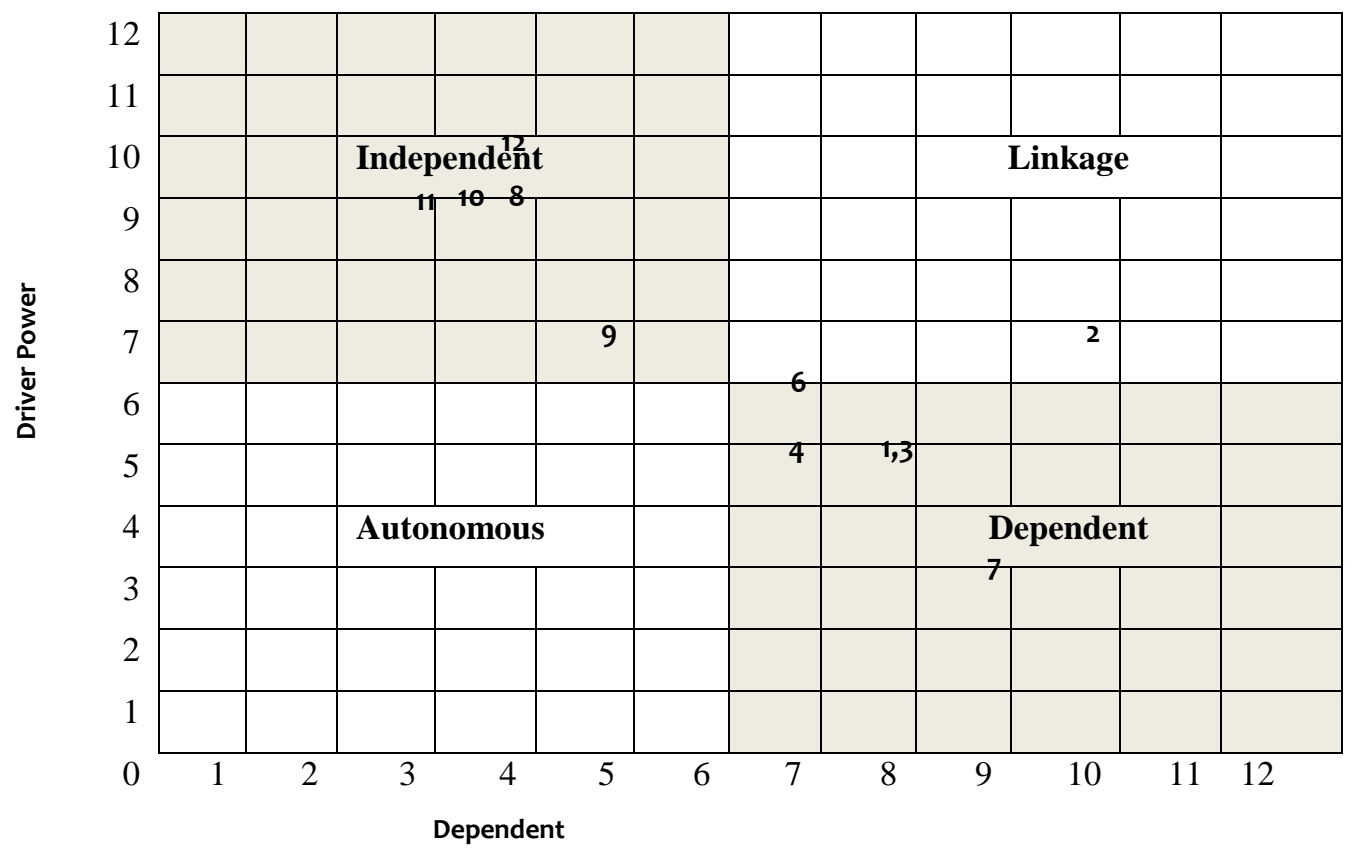

Gambar 4. Matriks DP-D Posisi Faktor-faktor penyebab banyak petani jagung beralih ke komoditi lain

Keterangan :

1. Mahal dan kurangnya benih unggul

2. Proses penanganan pasca panen yang kurang maksimal

3. Rendahnya tingkat pengetahuan petani

4. Kurang perhatian pemerintah daerah

5. Harga jagung yang tidak stabil

6. Lemahnya peran penyuluh

7. Tidak tersediahnya akses transportasi

8. Kurangnya pupuk bersubsidi

9. Kurangnya modal petani

$5^{10 .}$ Gangguan hama

11. Lemahnya Gapoktan

12. Lemahnya komitmen petani

Dapat kita lihat pada gambar 4 bahwa ada 7 sub elemen penyebab banyak petani jagung beralih ke komoditi lain diantaranya yaitu :

1. Harga jagung yang tidak stabil

Faktor penting yang menyebabkan petani jagung beralih ke komoditi lain, apabila pada saat musim panen tibah harga jagung turun drastis sebaliknya jika masa panen sudah berlalu harga jagung akan stabil kembali. Sehingga perekonomian petani jagung tidak meguntungkan dan tidak dapat lagi di jadikan sebagi prioritas sumber mata pencarian kelurga.Ketidakstabilan harga jagung di tingkat produsen mengakibatkan pemerintah melakukan upaya perbaikan harga jual petani.Hal ini dilakukan agar petani tidak semakin rugi akibat harga jual yang rendah.Harga 
Referensi Daerah (HRD) jagung sebagai standar pembelian jagung dari petani dengan mencari masukan dari berbagai pihak, termasuk kalangan pengusaha pakan ternak.Berdasarkan surat keputusan Ketapang SUMUT (2012), disebutkan bahwa Harga Referensi Daerah Jagung adalah harga minimum pembelian jagung di tingkat petani yang disepakati sebesar biaya produksi ditambah margin/keuntungan petani sebesar 30\% (tiga puluh persen) dari biaya produksi.

Salah satu upaya yang bisa di lakukan dengan tunda jual yaitu produksi jagung tidak langsung dijual tapi di simpan maka, diusulkan ada program untuk menjaga produksi dan stabilitas harga bagi dinas pertanian termasuk kerjasama dengan Perum BULOG dan industry pakan agar minat petani untuk berbudidaya jagung terus terpelihara dalam rangka mendukung ketahanan pangan dan faktor terpenting dalam pembentukan harga adalah kekuatan permintaan dan penawaran. Permintaan dan penawaran akan berada dalam keseimbangan pada harga pasar jika jumlah yang diminta sama dengan jumlah yang ditawarkan. Penerimaan usahatani adalah perkalian antara produksi yang diperoleh dengan harga jual. Pernyataan tersebut dapat dinyatakan dalam rumus sebagai berikut (Rahim, 2008)

2. Lemahnya komitmen petani

Lemahnya komitmen petani merupakan suatu kinerja petani yang tidak konsisten dalam melakukan budidaya tanaman jangung sehingga menyebabkan petani tidak fokus dalam satu komoditi.Ada kecenderunganbahwa semakin lama seseorang dalammenggeluti usahataninya/usaha semakinbanyak tahu baik buruknya usaha tersebutdan juga memilikibanyak pengetahuanuntuk dapat memilih inovasi yang baikuntuk pengembangan usahanya, Nurhapsa (2016).

Kepuasaan petani terhadap kegiatan penyuluhan rendah karena lemahnya interaksi petani dengan penyuluh yang berkaitan dengan jumlah dan kualitas penyuluh.Hal tersebut membuat peran penyuluh tidak optimal, serta penyuluhan yang dilakukan kurang sesuai dengan filosofi penyuluhan.Sumardjo (2010) menyatakan tingkat kompetensi penyuluh masih relative rendah. Tingkat kapasitas penyuluh yang cukup baik tidak akan berarti jika tidak dikaitkan dengan kepuasan petani terhadap kegiatan penyuluhan. Hal ini senada dengan penemuan (Sadono 2008) Penyuluhan pertanianmempunyai peran untuk 
membantu petani agar dapat menolong dirinya untuk mengatasi permasalahan yang dihadapinya secara baik dan memuaskan sehingga meningkat derajat kehidupannya. Ketika petani puas dengan kegiatan penyuluhan maka petani akan menjalankan anjuran-anjuran yang disarankan oleh penyuluh.

\section{Lemahnya Gapoktan}

Lemahnya gapoktan karena kurangnya kerja sama antar kelompok tani. satunyadisebabkan kelemahan regulasi yang menjadi dasar operasional Poktan/Gapoktan, di antaranya adalah: Pertama, Regulasi yang ada belum mengatur secara jelas syarat dan prosedur menjadi anggota, sehingga status keanggotaan Kelompok tani tidak jelas. Kedua,Ketidakjelasan status Poktan/ Gapoktan apakah sebagai organisasi sosial atau bisnis.

Kelembagaan petani yang sudah ada selama ini masih mempunyai beberapa kekurangan, sehingga belum dapat secara signifikan meningkatkan pendapatan petani. Hermanto dan Swastika (2011) menyimpulkan penguatan kelompok tani masih sangat perlu dilakukan melalui beberapa upaya, antara lain; (1) mendorong dan membimbing petani agar mampu bekerjasama di bidang ekonomi secara berkelompok,

menumbuh kembangkan kelompok tani melalui peningkatan fasilitasi bantuan dan akses permodalan, peningkatan posisi tawar, peningkatan fasilitasi dan pembinaan kepada organisasi kelompok, dan peningkatan efisiensi dan efektivitas usaha tani, serta (3) meningkatkan kapasitas SDM petani melalui berbagai kegiatan pendampingan dan latihan yang dirancang secara khusus bagi pengurus dan anggota. Secara teknis upaya penguatan kelompok tani ini dilakukan oleh Penyuluh Pertanian Lapangan (PPL).

\section{Gangguan Hama}

Hama yang menyerang tanaman jangung yaitu babi.Dampak dari serangan babi terjadi keruskan pada batang dan perakaran sehingga dapat menghambat penyerapan air dan hara dari tanah dan mengakibatkan tanaman menjadi mati. Metode untuk pengendalian terhadap hewan ini dilakukan lewat aktifitas perburuan dengan pemanfaatan hewan lain seperti anjing. Dalam Situs Direktorat Jendral Perkebunaan, Ratri Wibawanti 2016 Penelitiaan Hama, menyebutkan metode pengendalian langsung diaplikasikan lewat pemasangan jerat, racun, berburuh, pemasangan lampu, dan lubang parit. 
5. Kurangnya pupuk bersubsidi

Kurangnya pupuk bersubsidi mengakibatkan petani mengeluh karena pada saat melakukan pemupukan pada tanaman jagung, pupuk bersubsidi tidak mecukupi ketersediaan, petani ingin membeli pupuk non bersubsidi tapi dari segi modal tidak mencukupi sehingga petani terus menerus mengharapkan pupuk bersubsidi dari pemerintah.

Langkah untuk mengatasi dari kementrian pertanian hendak menyempurnakan program Electronic Rencana Definitive Kebutuhan Kelompok Elektronik (e-RDKK) dan Kartu Tani guna memperbaiki penanganan pupuk bersubsidi. Panjangnya rantai distribusi dan dualisme harga pupuk inimenimbulkan kelangkaan pupuk serta pengoplosan pupuk bersubsidi dan non subsidi serta lemahnya pengawasan dan pemalsuan kouta pupuk juga kerap terjadi. Untuk itu, dengan adanya e-RDKK dan Kartu Tani tidak akan terjadi kelangkaan pupuk bersubsidi.

\section{Kurangnya modal petani}

Permodalan sering menjadi masalah umum petani. Terlebih jika petani mengalami gagal panen karena kendala alam atau serangan hama dan penyakit. Belum lagi jika harga produk sedang anjlok.Hal ini membuat banyak petani tidak memiliki modal untuk melanjutkan usaha taninya.

Jika lahan petani memgalami cuaca esktrim maupun serangan hama sehingga gagal panen, harus ada langkah cepat agar petani mendapatkan modal kembali untuk memulai usahataninya maupun memulihkan kondisi lahan. Modal yang dibutuhkan tidak selalu jumlah besar, namun yang terpenting adalah harus didaptkan secara mudah dan cepat.

Salah satu peran pemerintah adalah 1.dengan membuat sebuah berbagai kebijakan yang dapat menguntungkan pihak pemodal maupun pihak yang bekerja dibidang pertanian melalui aplikasi yang dibuat, 2.memberikan sebuah perlindungan terhadap uang dari pemodal yang diberikan kepada pihak yang bekerja dibidang pertanian, 3 . pemerintah selalu memantau maupun memberikan sebuah sangsi kepada pihak - pihak yang melakukan sebuah tindakan kecurangan baik itu dari pihak pemodal maupun para pekerja dibidang pertanian.

7. Proses penanganan pasca panen yang kurang maksimal

Penanganan pasca panen (postharvest) sering disebut juga sebagai pengolahan primer (primary processing) merupakan istilah yang digunakan untuk semua perlakuan dari mulai panen sampai 
komoditas dapat dikonsumsi "segar" atau untuk persiapan pengolahan berikutnya.Penanganan pasca panen bertujuan agar hasil tanaman tersebut dalam kondisi baik dan sesuai/tepat untuk dapat segera dikonsumsi atau untuk bahan baku pengolahan

Keanekarangaman varietas dan di dukung oleh iklim yang sesuai untuk tanaman jangung akan menghasilkan buah yang baik. Di samping itu dengan area yang luas akan mengahasilan buah jangung yang banyak apabila dilakuakan panaen dan tidak ditangani dengan baik, pasti mengalami perubahan akibat pengaruh iklim atau lingkungan.

Program penanganan panen dan pascapanen hasil pertanian yang secara mendasar mempu memperbaiki kondisi yang telah diuraikan sebelumnya, harus merupakan program meliputi keseluruhan sistem panen dan pascapanen dan menyangkut seluruh aspek yang terkait yang mulai dari aspek sumberdaya manusia, budidaya hingga revitalisasi peralatan. Untuk mencapai apa yang diharapkan terutama turunnya kehilangan hasil dan meningkatkan mutu hasil maka diperlukan program yang terencana dan berbasis kepada pelaku utama yakni petani.
Dalam rangka penanganan kegiatan pascapanen dan pengolahan hasil pertanian kegiatan yang akan dilakukan dibidang pengembangan sarana pertanian antara lain : a). Mengembangkan peralatan pengering dan lumbung pangan; b). Bimbingan manajemen pengembangan sarana alat mesin pengolahan hasil pertanianbaik secara sosial, teknis maupun ekonomis; c). Menjalin kerjasama dengan peneliti, perekayasa, pelaku usaha pengolahan, petani dan pengusaha alat mesin pertanian dalam pengembangan sarana pengolahannya; d). Bimbingan teknis dan pembinaan kelompok usaha pengolahan hasil pertanian dan pembinaan pemanfaatan UPJA dan lain-lain; e). Bimbingan teknis pemanfaatan modal baik dari skim kredit PUKK atau dan dari BLM; f). Persewaan bengkel dan persewaan alat dan mesin pascapanen di tingkat lokalita; g). Peningkatan kemampuan sumberdaya manusia (pelatihan) dalam bidang pengembangan sarana pengolahan hasil pertanian di pedesaan.

\section{KESIMPULAN}

Berdasarkan hasil penelitian ada tujuh faktor yang mempengaruhi petani jagung beralih ke komoditi lain yaitu harga jagung yang tidak stabil, lemahnya komitmen petani, lemahnya gapoktan, 
gangguan hama, kurangnya pupuk bersubsidi, kurangnya modal petani dan proses penanganan pasca panen yang kurang maksimal. Namun bisa teratasi di akibatakan adanya upaya peran kelembagaan pemerintah untuk mengatasi permasalahan yang dialami oleh petani.

\section{DAFTAR PUSTAKA}

Badan Pusat Statistik Jakarta Pusat, 2011. Statistik Indonesia Tahun 2011. Jakarta Pusat : Badan Pusat Statistik Desiana, C., D. Rochdiani, \&C. Pardani. (2017). Analisis Saluran Pemasaran

Eriyatno \& F.Sofyar.2007.Riset Kebijakan.Metode Penelitian untuk Pascasarjana. Penerbit IPB Press.

Hermanto\& Swastika, 2011. Ilmu Usahatani. Penerbit Swadaya, Jakarta.

Nurhapsa \& Andi Nuddin.2016. Efesiensi Saluran Pemasaran Kopi Arabika Di Kabupaten Enrekang. Sinergitas Multidisiplin Ilmu Pengetahuan dan Teknologi, vol. 1, 2018, ISSN:2622-0520

Rahim, dkk. 2008. Ekonomika Pertanian. Penebar Swadaya. Jakarta

Ratri Wibawanti. 2016. Pengendalian OPT Tanaman Cengkeh. Direktorat Perlindungan Perkebunan, Direktorat Jenderal Perkebunan, Kementerian Pertanian. Jakarta
Sumardjo. 2010. Model Pemberdayaan Masayarakat Dan Pengelolaan Konflik Sosial Pada Perkebunan Kelapa Sawit Di Propinsi Riau. Riau.287 Hal.

Sudrajat, J., J. H. Mulyo, S. Hartono, \&Subejo. (2014). Analisis Efisiensi dan Kelembagaan Pemasaran Jagung di Kabupaten Bengkayang. Jurnal Social Economic of Agriculture, Volume 3(1): 14-23.

Ketapang SUMUT. 2012. Kesepakatan Harga Referensi Daerah Jagung Tahun 2012 di Provinsi Sumatera Utara

Sadono. 2008.Mikro Ekonomi Teori Pengantar. Jakarta: P.T Raja GrafindoPersada. 